\title{
Abnormal radionuclide liver scans in giant cell arteritis
}

\author{
J. JONES, ${ }^{1}$ M. V. KYLE, ${ }^{2}$ BRIAN L. HAZLEMAN ${ }^{2}$ AND PHILIP WRAIGHT ${ }^{3}$ \\ From the 'Department of Rheumatology, Kings College Hospital, Denmark Hill, London, and the \\ ${ }^{2}$ Department of Rheumatology and 'Department of Nuclear Medicine, Addenbrooke's Hospital, Hills Road, \\ Cambridge
}

SUMMARY In the investigation of six patients with giant cell arteritis and abnormal liver function radionuclide liver scans were found to be abnormal in all. The abnormality may be due to arteritis of hepatic vessels. It is important to recognise that giant cell arteritis may cause liver scan abnormalities. If other pathology is suspected and corticosteroid treatment delayed while further investigations are carried out, patients are at risk of complications such as blindness.

Routine liver function tests are frequently abnormal in patients with giant cell arteritis and polymyalgia (GCA and PMR). Elevation of alkaline phosphatase is seen in up to $70 \%$ of patients with GCA and/or PMR. ${ }^{12}$ Serum albumin is often low, ${ }^{34}$ and there may be modest elevation of transaminases. ${ }^{145}$ Abnormal retention of bromsulphalein is common ${ }^{4}$ and a prolonged half life of galactose was noted in one-third of the patients described by Malmvall and Bengtsson. ${ }^{7}$ The underlying pathological process which produces these changes and its relationship to the pathogenesis of the condition have yet to be adequately explained. Although biochemical and histological studies of the liver have been frequently reported, there are only 10 reports of radionuclide scanning of the liver in GCA.

Accepted for publication 21 February 1984.

Correspondence to $\mathrm{Dr} \mathrm{V}$. Kyle, Rheumatology Research Unit, Unit E6, Addenbrooke's Hospital, Hills Road, Cambridge CB2 $2 \mathrm{QQ}$.
We therefore wish to report the results of radionuclide scanning of the liver in six patients with GCA.

\section{Patients and methods}

Six patients had radionuclide liver scans carried out during investigation of abnormal liver function tests, before the diagnosis of PMR/GCA was made. These patients were part of a retrospective study of 108 patients with PMR/GCA, of whom $72 \%$ had a raised alkaline phosphatase level. Only the six patients discussed here had scans performed. None gave a history of excessive alcohol intake, and other causes of hepatomegaly and abnormal liver function were excluded.

Clinical details. The main features on presentation are shown in Table 1 . Three had a mixed picture of PMR and GCA, and three had GCA only. All six fulfilled our diagnostic criteria for PMR/GCA. ${ }^{8}$

Table 1 Clinical details

\begin{tabular}{|c|c|c|c|c|c|c|}
\hline & $\begin{array}{l}\text { Age } \\
\text { (years) }\end{array}$ & Sex & Headache & $\begin{array}{l}\text { Visual } \\
\text { symptoms }\end{array}$ & $\begin{array}{l}\text { Weight } \\
\text { loss }\end{array}$ & $\begin{array}{l}\text { Muscle pain } \\
\text { and stiffness }\end{array}$ \\
\hline 1 & 62 & $\mathbf{M}$ & - & + & - & + \\
\hline 2 & 68 & $F$ & + & + & + & + \\
\hline 3 & 71 & $F$ & + & - & + & + \\
\hline 4 & 68 & $\mathbf{M}$ & + & + & - & - \\
\hline 5 & 64 & $F$ & + & - & + & - \\
\hline 6 & 64 & $\mathbf{F}$ & + & - & + & - \\
\hline
\end{tabular}

$+=$ Present. $-=$ Not present. $M=$ male. $F=$ female. 
Table 2 Investigations

\begin{tabular}{|c|c|c|c|c|c|c|c|}
\hline & $\begin{array}{l}H b \\
(g / d l)\end{array}$ & $\begin{array}{l}E S R \\
(\mathrm{~mm} / \mathrm{h})\end{array}$ & $\begin{array}{l}\text { Alk. phosph. } \\
\text { (34-92 IU/l) }\end{array}$ & Albumin & Globulin & $\begin{array}{l}\text { TA } \\
\text { biopsy }\end{array}$ & $\begin{array}{l}\text { Liver } \\
\text { biopsy }\end{array}$ \\
\hline 1 & $12 \cdot 3$ & 103 & 1100 & $\downarrow$ & $\uparrow$ & ND & $\mathrm{N}$ \\
\hline 2 & $7 \cdot 4$ & 60 & 152 & $\downarrow$ & ND & GCA & ND \\
\hline 3 & $7 \cdot 4$ & 112 & 103 & $\downarrow$ & $\uparrow$ & $\mathrm{GCA}$ & ND \\
\hline 4 & 10.8 & 130 & 680 & $\downarrow$ & ND & GCA & Abn \\
\hline 5 & 10.6 & 114 & 119 & $\mathrm{~N}$ & $\uparrow$ & Failed & Abn \\
\hline 6 & 7.9 & 140 & 158 & $\downarrow$ & $\uparrow$ & GCA & $\mathbf{N}$ \\
\hline
\end{tabular}

$\mathrm{ND}=$ not done. $\mathrm{N}=$ normal. Abn=abnormal. $\mathrm{TA}=$ temporal artery. $\downarrow=$ Decreased. $\uparrow=$ Increased.

Table 3 Radionuclide scans

\begin{tabular}{llll}
\hline & Hepatomegaly & $\begin{array}{l}\text { Patchy tracer } \\
\text { distribution }\end{array}$ & $\begin{array}{l}\text { Focal } \\
\text { lesions }\end{array}$ \\
\hline 1 & ++ & ++ & + \\
2 & ++ & ++ & + \\
3 & + & + & - \\
4 & ++ & - & - \\
5 & ++ & + & - \\
6 & ++ & ++ & \pm \\
\hline
\end{tabular}

$+=$ Present. $++=$ Marked. $\pm=$ Possible.

Investigations. Haemoglobin, ESR (Westergren), alkaline phosphatase, and albumin levels were measured in all patients. Protein electrophoresis, temporal artery biopsy, and liver biopsy were also performed in most of the patients. These results are summarised in Table 2. The abnormal liver biopsies showed only non-specific changes.

Radionuclide scans. $2 \mathrm{mCi}$ of ${ }^{99_{\mathrm{m}}}$ technetium sulphur colloid were injected into an antecubital vein. After at least 20 minutes the patients were scanned with an Elscint double-headed rectilinear scanner. Anterior, posterior and right and left hand views were taken in all cases. Table 3 summarises the results of the radionuclide liver scans. All were abnormal.

Follow-up. Liver function tests returned to normal in all six patients after treatment with oral corticosteroids.

\section{Discussion}

There are few reports of the use of radionuclide liver scanning in GCA. Normal scans have been reported in eight patients ${ }^{5-14}$ and focal defects have been described in two cases. ${ }^{12} 15$

The pathogenesis underlying abnormal liver function tests remains unclear. Most liver biopsies in GCA are normal or show minor non-specific changes. There are two reports of arteritis, one of the hepatic artery at necropsy, ${ }^{16}$ and one of the portal tract arteries and septal vessels. ${ }^{14}$ Hepatic granulomata have been reported in a few cases. $^{1011} 17$ Von Knorring and Wasatjerna ${ }^{18}$ proposed that parenchymal inflammation was present because of their finding of lymphocytes and increased alkaline phosphatase activity in the bile canaliculi, and the work of Leong and $\mathrm{Alp}^{13}$ also supports this. Patchy deposition of immune complexes in the hepatic arteries has been proposed by McCormack et al. ${ }^{5}$ but remains unproved. Reports of primary biliary cirrhosis occurring with PMR $\mathrm{GCA}^{19-21}$ were not fully substantiated.

In the cases we have reported here it is impossible to identify a specific abnormality causing the varying scan findings and biopsy results. Arteritis of the hepatic vessels would be most likely (of all the possibilities suggested) to cause the abnormalities seen.

The clinical implications are important. It is not generally recognised that liver scans may be abnormal in PMR/GCA. In patients presenting with non-specific features the finding of an abnormal radionuclide scan may mislead the physician into suspecting underlying malignancy. Even if PMR/ GCA is suspected, additional pathology may still be sought. Treatment with steroids may be delayed, putting the patient at risk of complications such as blindness.

Liver function tests and liver size returned to normal in all our patients after treatment with steroids. It seems likely that the scans also reverted to normal, but unfortunately follow-up scans were not obtained. A prospective study is planned to investigate further these previously unreported liver scan abnormalities in PMR/GCA.

We thank the physicians at Addenbrooke's Hospital who allowed us to study their patients. We would also like to thank the Arthritis and Rheumatism Council for its continued support.

\section{References}

1 Wadman B, Werner I. Observations on temporal arteritis. Acta Med Scand 1972; 192: 377-83. 
2 Jones J G, Hazleman B L. Polymyalgia rheumatica (PMR) and giant cell arteritis (GCA)-a difficult diagnosis. $J R$ Coll Gen Pract 1981: 31: 283-9.

3 Fauchald P. Rygvold O. Oystese B. Temporal arteritis and polymyalgia rheumatica: clinical and biopsy findings. Ann Intern Med 1972: 77: 845-52.

4 Dickson E R, Maldonado J E. Sheps S G. Cain J A. Systemic giant cell arteritis with polymyalgia rheumatica. Reversible abnormalities of liver function. JAMA 1973; 224: 1496-8.

5 McCormack L R. Astarita R W. Foroozan P. Liver involvement in giant cell arteritis. Digest Dis 1978; 23: 72s-4s.

6 Hunder G G. Sheps S G, Allen G L, Joyce J W. Daily and alternate-day corticosteroid regimes in treatment of giant cell arteritis. Ann Intern Med 1975; 82: 613-8.

7 Malmvall B E, Bengtsson B A. GCA clinical features and involvement of different organs. Scand J Rheumatol 1978; 7: 154-8.

8 Jones J G, Hazleman B L. Prognosis and management of polymyalgia rhcumatica. Ann Rheum Dis 1981; 40: 1-5

9 Jones J G. Polymyalgia rheumatica in the setting of a general hospital. Submitted as MD thesis. University of London 1983.

10 Long R, James O. Polymyalgia rheumatica and liver disease. Lancet 1974; i: 77-9.

11 Litwach K D, Bohan A. Silverman L. Granulomatous liver disease and giant cell arteritis. J Rheumatol 1977; 4: 307-12.

12 Ghose M K, Shensa S, Lerner P I. Arteritis of the aged (giant cell arteritis) and fever of unexplained origin. Am J Med 1976 60: $429-36$

13 Leong A S-Y, Alp M H. Hepatocellular disease in giant cell arteritis/polymyalgia rheumatica syndrome. Ann Rheum Dis 1981; 40: 92-5.

14 Ogilvie A L, James P D, Toghill P J. Hepatic artery involvement in polymyalgia arteritica. J Clin Pathol 1981; 34: $769-72$.

15 Mann D C. Toole J F. Cranial arteritis with liver involvement Stroke 1972; 3: 131-4.

16 Heptinstall R H, Porter K A. Barkley H. Giant cell (temporal) arteritis. J Pathol Bacteriol 1954; 67: 507-19.

17 Kosolcharoen P, Magnin G E. Liver dysfunction and polymyalgia rheumatica. A case report. J Rheumatol 1976; 3: 50-3.

18 Von Knorring J, Wasatjerna C. Liver involvement in polymyalgia rheumatica. Scand J Rheumatol 1976; 5: 197-204.

19 Robertson J C, Batstone G F, Loebl W Y. Polymyalgia rheumatica and primary biliary cirrhosis. $\mathrm{Br}$ Med $J$ 1978; ii: 1128.

20 Hamblin T J. Significance of antimitochondrial antibodies. Lancet 1981; ii: $1411-2$.

21 Sattar M A, Cawley M I D, Robertson J C. Polymyalgia rheumatica and antimitochondrial antibodies. In: Combined meeting of British Association for Rheumatology and Rehabilitation, the Heberden Society, and Royal Society of Medicine. 1981.

\section{Book review}

Management of Rheumatic Disorders. By J. M. H. Moll. Pp. 386. £29.50. Chapman and Hall: Andover, Hants. 1983.

It is unusual now for a subject as wide as this to be tackled in a lengthy textbook by a single author. Dr Moll has tried to encompass the whole spectrum of management and has succeeded.

Although, inevitably, a large proportion of the book is taken up with a consideration of drugs, a fair appreciation is given to assessment, physical treatment and surgical treatment of the rheumatic diseases. The historical sections in the first chapter and the general principles of treatment in the second are both of lasting interest and value. The sections on drugs are most comprehensive but have already dated-for example, the recent withdrawal of certain anti-inflammatory analgesics-and to remain useful will need regular revision. The author is to be congratulated on his most comprehensive bibliography throughout the book.

I find this a useful reference work but think that it would need frequent revision to remain current. It deserves a place on the shelves of medical libraries especially for non-specialists, junior staff, and students. The problem of regular updating is one which the author and publishers will need to consider.

COLIN G. BARNES 